\title{
The Local Wisdom of the Mbaba Belo Selambar Tradition of the Karo Community in the Village of TanjungLangkat, Sub-District of SalapianLangkat Regency North Sumatra: Anthropolinguistic Studies
}

\author{
Nova Indah Permatasari ${ }^{1}$, Robert Sibarani ${ }^{2 *}$, Pujiati $^{3}$ \\ ${ }^{1}$ Postgraduate Program Linguistics Study Program, Faculty of Cultural Sciences, University of Sumatera Utara \\ ${ }^{2 *}$ Faculty of Cultural Sciences, Universitas Sumatera Utara, Indonesia \\ ${ }^{3}$ Faculty of Cultural Sciences, Universitas Sumatera Utara, Indonesia \\ * Corresponding Author: \\ *Email: rs.sibarani@usu.ac.id

\begin{abstract}
.
This study aims to describe the local keraifan in the tradition of mbababeloselambar in the karo community in the village of TanjungLangkat, sub-district of Sal Api, district of LangkatPovinsi North Sumatra. Local wisdom in the tradition of mbababeloselambar can be seen in each of the stages that exist in the tradition. Local wisdom is a cultural heritage that always exists in a tradition and can be preserved for generations to come. The method used in this tradition is the qualitative method. The data used in this research is local wisdom that exists in this tradition. The results of this study are there are five (5) local wisdoms that exist in the tradition of mbababeloselambar, namely hard work, kinship, courtesy, harmony, responsibility and commitment.
\end{abstract}

Key words: mbababeloselambar, local wisdom,karo Community

\section{INTRODUCTION}

Mbaba is not as deliciousis one of the traditions owned by the karo community. Mbababeloselmabar is a ritual to propose to a girl, the marriage is carried out by the male side's family to the female side. This marriage ceremony was conducted to ask the willingness of the girl and her family. In this tradition, it does not only ask the willingness of the girl and her family but the willingness of Sembuyak, anakberu, singalobere-bere, and kalimbubu. Mbababeloselmabar begins with the submission of the presentation skills by the men to the women. In this tradition, the men must prepare six kampils. The kampil contains cigarettes and betel tableware. The tradition of mbababeloselambar shows that the khanza culture of the Karo community is seen from a linguistic point of view and local wisdom that exists in each of its implementers.

Culture is never separated from the role of language and its preservation includes the tradition of mbababeloselambar. In every implementation of this tradition always has the role of language and also the preservation of culture. Language and cultural preservation can be studied with an anthropolinguistic approach. Anthropolinguistics is a science that examines language as a source of culture and speaking as a cultural practice (Duranti, 1997). Anthropology can be called ethnolinguistic studying language not only from its structure but more on its function and usage. Anthropolinguistic studies include examining kinship through kinship terms, color concepts, parenting patterns or examining how community members communicate with each other in certain situations such as in traditional ceremonies, then linking them to cultural concepts.

Local wisdom is the original wisdom or knowledge of a community that comes from the noble values of cultural traditions to regulate the order of people's lives (Sibarani, 2014: 115). If it is focused on cultural values it can also be defined in other ways. Local wisdom is a local cultural value that can be used to regulate the order of community life wisely and wisely. Local wisdom of a culture is belonging to a community whose attitudes and 
personalities are ripe to be able to develop local potential and resources in making better changes. Values and cultures that are believed to be true become indifferent to the behavior of the local community. Humans have wisdom from three sources, namely cultural values called local wisdom from modern government regulations and from a religious perspective. Of the three sources of local wisdom, humans live their lives in the context of the interaction of the natural environment and the social environment. In his time, the two interaction spaces produced new values and norms that applied to the community and were different from the cultures of other communities.

Sibarani classifies local wisdom into two parts, namely local wisdom that is useful for improving welfare and local wisdom that is useful for creating peace can be seen in the following picture:

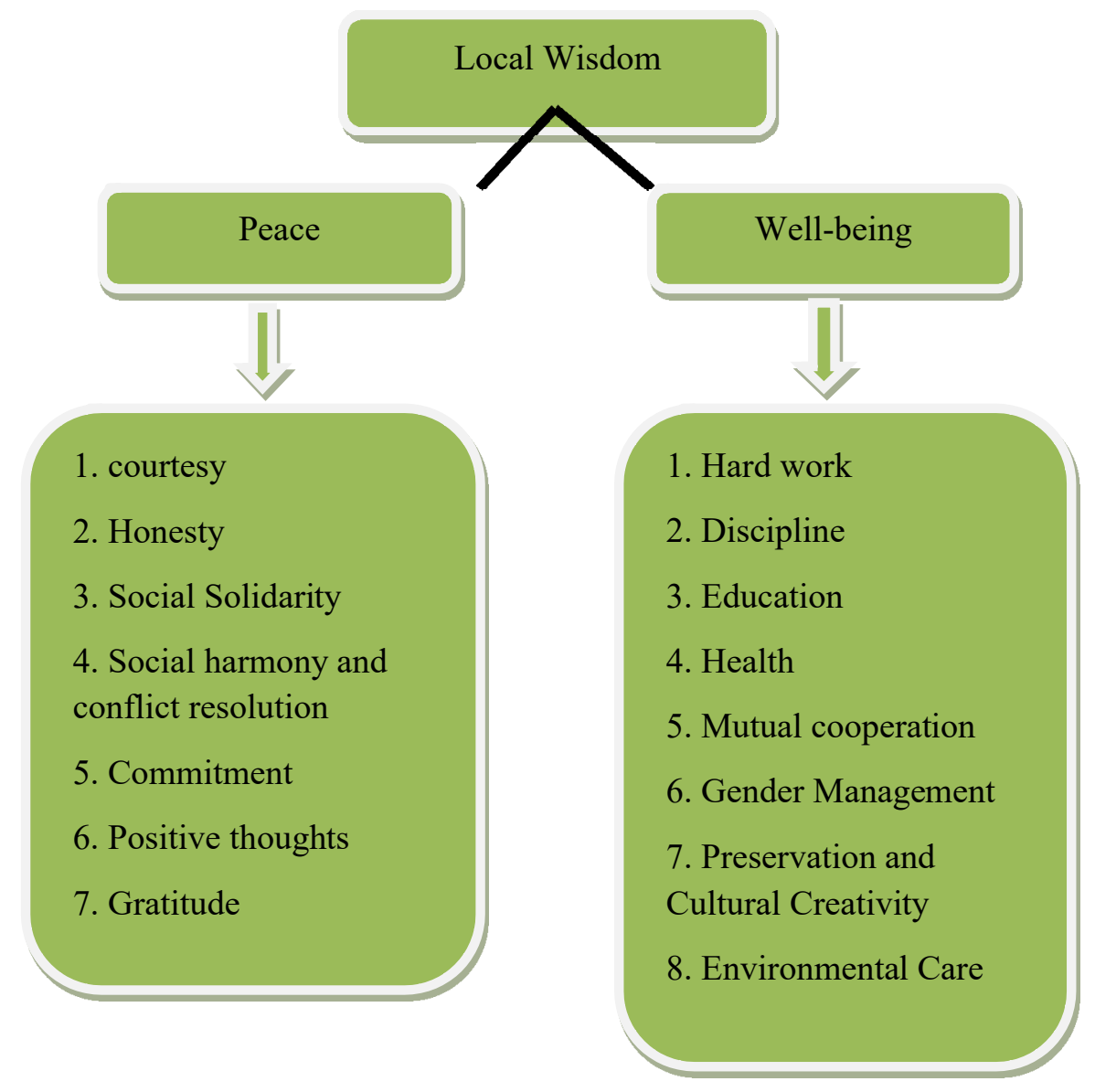

\section{METHODS}

The method used in this research is qualitative method. Qualitative method is a method used to examine the condition of natural objects and this qualitative research itself emphasizes meaning rather than generalization. This study also applies data analysis techniques using an interactive model proposed by Miels and Huberman (2014). The interactive model is a qualitative data analysis that is carried out interactively and continues until the data is clear. The interactive model applies three steps in analyzing data, namely, condensing data, presenting data and drawing conclusions and data verification. The following is a chart of the interactive model proposed by Miels and Huberman (2014): 


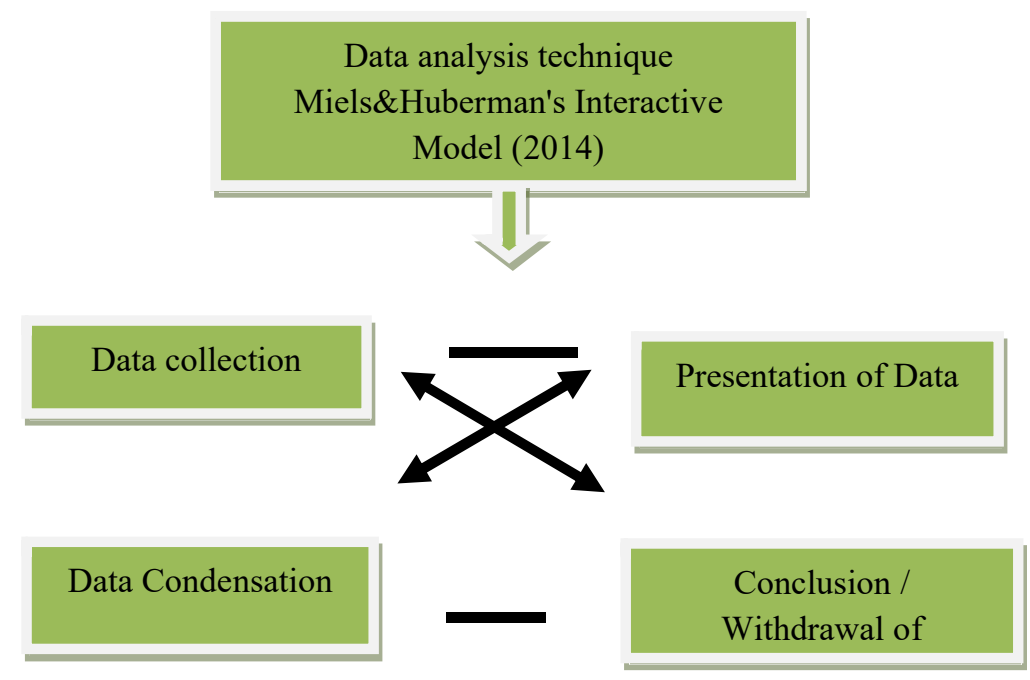

\section{RESULT AND DISCUSSION}

Local wisdom in the tradition of mbababeloselambar is an image of the Karo community in general who have highly upheld the values of brotherhood and kinship since ancient times. Local wisdom is a core part of the meaning of a tradition. Local wisdom is one of the core parts of a tradition. This type of local wisdom from the mbababeloselambar tradition generally functions as peace and well-being. The following are the types and explanations of local wisdom contained in the mbababeloselmabar tradition:

\begin{tabular}{|c|c|c|}
\hline No. & Local culture & Explanation \\
\hline 1. & $\begin{array}{lr}\text { Social } & \text { solidarity } \\
\text { and } & \text { mutual } \\
\text { cooperation }\end{array}$ & $\begin{array}{l}\text { Social solidarity and mutual cooperation is one form of local keraifan owned } \\
\text { by the Karo community. Social solidarity and mutual cooperation are found } \\
\text { in the tradition of mbababeloselambar, which is to prepare for the } \\
\text { mbababeloselambar event from the initial stage of the event until the method } \\
\text { is completed. Beru children, kalimbubu, pembibin, singalobere-bere, they are } \\
\text { people who have an important role in this tradition. They both prepare the } \\
\text { event starting from the needs that will be used in the event. }\end{array}$ \\
\hline 2. & Kinship & $\begin{array}{l}\text { Kinship in this tradition is how many family and relatives who have been } \\
\text { invited and come in the implementation of the mbababeloselambar tradition. } \\
\text { Traditional events are also a place to meet and gather for all extended } \\
\text { families and as an event of friendship. Wijud from kinship in the tradition of } \\
\text { mbaba, beloselmabar, the number of families who have come and together } \\
\text { they prepare the event until it ends well. }\end{array}$ \\
\hline 3. & Discipline & $\begin{array}{l}\text { The discipline in this tradition is that the event is carried out on time, at } \\
10.00-11.00 \text { WIB. The Karo community highly upholds discipline in } \\
\text { carrying out a tradition because discipline is very important in a tradition } \\
\text { because discipline will make them always be blessed with blessings and } \\
\text { sustenance from Allah SWT and provide happiness in their families. }\end{array}$ \\
\hline 4. & Gratitude & $\begin{array}{l}\text { Gratitude in the implementation of the tradition of mbababeloselambar is a } \\
\text { sense of happiness, hope and prayer because their daughters do mbababelo as } \\
\text { selambar with the boy of his choice. In addition to prayer and hope, symbolic }\end{array}$ \\
\hline
\end{tabular}




\begin{tabular}{|l|l|l|}
\hline | & $\begin{array}{l}\text { meaning is also found in some foods that exist in this tradition, such as cimpa } \\
\text { and cipera. The meaning of cimpa and cipera is so that later they live happily } \\
\text { together and live happily in their household, just like cimpa which tastes } \\
\text { sweet so that they are always given happiness. With this tradition, we can } \\
\text { also provide various sustenance for families and neighbors so that they are } \\
\text { given abundant sustenance by the creator. }\end{array}$ \\
\hline 5. & $\begin{array}{l}\text { Cultural } \\
\text { Preservation }\end{array}$ & $\begin{array}{l}\text { Cultural preservation in the tradition of mbababeloselambar is a tradition } \\
\text { held by the Karo community who also gets a candidate for the Karo } \\
\text { community. This tradition is carried out as a form of happiness from the } \\
\text { family. This tradition requires runggunmbababeloselambar consisting of } \\
\text { kalimbubu, anakberu, singalobere-bere, and pembibin. In the implementation } \\
\text { of this tradition they play an important role as long as the tradition lasts. The } \\
\text { implementation of this tradition requires all guests present to wear the } \\
\text { traditional karo cloth, namely uis. Karo traditional cloth (Uis) symbolizes } \\
\text { that a tradition carried out by the karo community never differentiates } \\
\text { between rank, position, or class when it is in the implementation of adat, } \\
\text { their position is the same. }\end{array}$ \\
\hline
\end{tabular}

\section{CONCLUSION}

From the explanation above, it can be concluded that the tradition of mbaba belo selambar is a tradition in the karo community which has many meanings of local values and wisdom in it. Mbaba belo selambar is also a cultural heritage that must be preserved so that it can be carried out in today's modern era. In the implementation of the mbaba belo selambar tradition, there are five local wisdoms contained in it, namely social solidarity and mutual cooperation, kinship, discipline, gratitude and cultural preservation.

\section{REFERENCES}

[1] Aslan. The Values of Local Wisdom in the Abstinence Culture of the Samba Malay Tribe. Researchgate Journal. DOI: 10.18592 / jiiu.16i1.1438 (2017).

[2] Chris, Mery Isabela Saragih. 2015. The Tradition of MamongkotRumah in Simalngun Society: Anthropolinguistic Study. Thesis.

[3] Duranti, Alessandro. 1997. Linguistic Anthropology. Cambrid University.

[4] Manugeren, M, Sibarani, Robert, NasutionIkhwanudin, Takari Muhammad. Local Wisdom in Hindu Tamil Ethnic Wedding Tradition in Medan.International Journal of Research in Humanities \&Soc.sciences [IF = 1.5]. Vol. 5 (2017).

[5] Miles, Huberman, Saldana. 2014. Qualitative Data Analysis: a Methods Sourcebook: America. Arizona State University.

[6] Monica et al. 2020. Oral Traditions of the Batak Toba Sur Matua Traditional Ceremony: An Anthropolinuistic Overview. Journal of Language, Literature, Arts and Culture. Volume 4, Number 3. Pages: 422-429.

[7] Sibarani, Robert. Anthropolinguistic Approach to the Study of Oral Traditions. Journal of Rhetoric Language Science. Vol 1, No 1 (2015).

[8] Sibarani, Robert. Anthropolinguistic Approach in Exploring Local Wisdom as National Identity. Proceedings of 5th International Comperence on Indonesia Studies "Ethnicity and Globalization. 2013.

[9] Sibarai, Robert. 2014. Local Wisdom: The Nature, Role and Methods of Oral Traditions. South Jakarta: Association of Oral Traditions.

[10] Sibarani, Robert. Batak Society's Local Wisdom of Mutual Cooperation in Toba Lake Area: a Linguistic Anthropology Study, International Journal of Human Rights in Healthcre. Vol.1 No 1.2018. 
[11] Sitompul, et al. 2017. Analysis of the Functions of Cultural Values and Local Wisdom in SinamotKaryaMuda Medan: Anthropolinguistic Study. Journal of the Faculty of Teacher Training and Education. Volume-4, Edition-2.

[12] Sukmayadi, Trisna. Local Wisdom Values in the Life View of the People of KampungKuta. Researchgate Journal. DOI; 10.24269 / jpk.v3.nl.2018.pp19-29 (2018).

[13] Ulina, Sri BeruGinting. The Semiotic Meaning of Discourse to Build Belo Selambar Adat Karo Langkat (Social Semiotics study). Indonesian Pen Journal (JPI). Vol 3, No 2 (2018). 